K. R. Hordiei, T. M. Gontova, M. Yu. Zolotaikina

National University of Pharmacy

\title{
The study on the elemental composition of the feverfew herb (Tanacetum parthenium (L.) Schultz bip.)
}

Macro- and microelements affect the vital functions of plants; they are an integral part of the medicinal plant raw material and play a significant role in the pharmacological activity of herbal medicines. Expediency of determination of the heavy metals content is stipulated by the requirements to the raw material. Within the standardization of the feverfew raw material batches the comparative study of the elemental composition of the herb depending on the regions of the raw material collection has been conducted.

Aim. To analyze the degree of accumulation of macro- and microelements of the feverfew herb collected in 7 regions of Ukraine.

Materials and methods. The study object was batches of the feverfew herb collected in 7 regions of Ukraine. The qualitative composition and quantitative content of the elements were determined using the atomic emission spectroscopy method at the Laboratory of Analytical Chemistry of Functional Materials and Environmental Objects of the STC "Institute for Single Crystals", National Academy of Sciences of Ukraine (Kharkiv) using a CAS-120 device, manufacturing group "Electron" by atomization in air-acetylene flame.

Results and discussion. As a result of the study conducted 18 elements were identified in all batches of the raw material. The prevailing content of potassium was identified in the samples from the Kharkiv, Zhytomyr and Poltava regions. The calcium content prevailed in the samples from the Kharkiv, Zhytomyr and Cherkasy regions. The greatest content of silicon and magnesium was identified in the samples from the Kharkiv and Zhytomyr regions. Nickel, molybdenum and lead were in the least quantity among the microelements in the feverfew herb. The content of cobalt, cadmium, arsenic and mercury was within the maximum permissible limits.

Conclusions. For the first time the study of the mineral composition of samples of the feverfew herb from different regions of Ukraine was carried out using the atomic emission spectroscopy. The studies conducted indicate that the content of potassium, calcium, silicon and magnesium prevails in all samples of the raw material.

Key words: feverfew (Tanacetum parthenium); mineral composition; atomic emission spectrophotometry; macro- and microelements

\section{К. Р. Гордєй, Т. М. Гонтова, М. Ю. Золотайкіна}

\section{Дослідження елементного складу трави маруни дівочої (Tanacetum parthenium (L.) Schultz bip.)}

Макро- та мікроелементи впливають на життєві фрункції рослин, є невід'ємною складовою лікарської рослинної сировини і відіграють значну роль у фармакологічній активності рослинних лікарських засобів. Доцільність визначення вмісту важких металів обумовлена вимогами до якості сировини. У рамках стандартизації серій сировини маруни дівочої - Tanacetum parthenium (L.) Schultz bip. було проведено порівняльне вивчення елементного складу трави в залежності від регіону заготівлі.

Мета. Проаналізувати ступінь накопичення макро- та мікроелементів у 7 серіях трави маруни дівочої, заготовленої в різних областях України.

Матеріали та методи. Об'єктом дослідження були серії трави маруни дівочої, зібраної у 7 областях України. Накопичення макро- та мікроелементів визначали методом атомно-адсорбційної спектроскопії з атомізацією в повітряно-ацетиленовому полум'ї на приладі КАС-120 на базі НТК «Інститут монокристалів» НАН України.

Результати та їх обговорення. В результаті проведеного дослідження у всіх серіях ЛРС виявлено та визначено вміст 18 елементів. Переважна кількість калію визначена у зразках з Харківської, Житомирської та Полтавської областей. Вміст кальцію переважав у зразках з Харківської, Житомирської та Черкаської областей. Найбільший вміст силіцію та магнію спостерігався у зразках з Харківської та Житомирської областей. Серед мікроелементів у траві маруни в найменшій кількості знаходились нікель, молібден і плюмбум. Вміст кобальту, кадмію, арсену та меркурію знаходився в межах гранично допустимих концентрацій.

Висновки. Вперше методом атомно-адсорбційної спектрофротометрії вивчено накопичення макро- та мікроелементів у зразках трави маруни дівочої, заготовлених у різних областях України. Проведені дослідження свідчать про значний вміст калію, кальцію, силіцію та магнію в усіх зразках сировини.

Ключові слова: маруна дівоча (Tanacetum parthenium); мінеральний склад; атомно-емісійна спектроскопія; макро- та мікроелементи 


\section{Исследование элементного состава травы пижмы девичьей (Tanacetum parthenium (L.) Schultz bip.)}

Макро- и микроэлементы влияют на жизненные функции растений, являются составляющей лекарственного растительного сырья и играют значительную роль в фармакологической активности растительных лекарственных средств. Целесообразность определения содержания тяжелых металлов обусловлена требованиями к качеству сырья. В рамках стандартизации серий сырья пижмы девичьей - Tanacetum parthenium (L.) Schultz bip. было проведено сравнительное изучение элементного состава травы в зависимости от региона заготовки.

Цель. Проанализировать степень накопления макро- и микроэлементов в 7 сериях травы пижмы девичьей, заготовленной в разных областях Украины.

Материалы и методы. Объектом исследования были серии травы пижмы девичьей, заготовленной в 7 областях Украины. Накопление макро- и микроэлементов определяли методом атомно-адсорбционной спектроскопии с атомизацией в воздушно-ацетиленовом пламени на приборе КАС-120 на базе НТК «Институт монокристаллов» НАН Украины.

Результаты и их обсуждение. В результате проведенного исследования во всех сериях ЛРС обнаружено и определено содержание 18 элементов. Преобладающее количество калия определено в образцах из Харьковской, Житомирской и Полтавской областей. Содержание кальция преобладало в образцах из Харьковской, Житомирской и Черкасской областей. Наибольшее содержание кремния и магния наблюдалось в образцах из Харьковской и Житомирской областей. Среди микроэлементов в траве пижмы девичьей в наименьшем количестве были никель, молибден и свинец. Содержание кобальта, кадмия, мышьяка и меркурия находилось в пределах гранично допустимых концентраций.

Выводы. Впервые методом атомно-адсорбционной спектрофотометрии изучено накопление макро- и микроэлементов в образцах травы пижмы девичьей, заготовленной в разных областях Украины. Проведенные исследования свидетельствуют о значительном содержаним калия, кальция, кремния и магния во всех образцах сырья.

Ключевые слова: пижма девичья (Tanacetum parthenium); минеральный состав; атомно-эмиссионная спектроскопия; макро- и микроэлементы

The human organism is a coherent system that functions harmoniously due to the optimal composition of many compounds. It is known that 31 compounds are essential for a person, including 8 amino acids, 12 vitamins and 11 mineral elements $[1,2]$.

Plants are the main source of minerals since they absorb elements from the soil and through the transpiration stream of water provide the tissues and organs of the plant organism with them. Mineral compounds getting into the human organism act as regulators of over 50,000 biochemical processes and normalize metabo$\operatorname{lism}[3,4]$.

Excess or deficiency of elements causes significant pathological changes in the human organism.

The study of the elemental composition of the raw material of promising medicinal plants is of current interest since it is known that macro- and microelements that are part of plant organs affect the biological activity of herbal medicinal products on its basis $[5,6,7]$.

Feverfew (Tanacetum parthenium (L.) Schultz Bip.), a plant of the genus Tanacetum is widely used in folk medicine. This is a perennial herbaceous plant originating from Eurasia, Asia Minor and the Balkan Peninsula; it is widely cultivated in Ukraine and other European countries $[8,9]$. The main indications for the use of the feverfew herb are inflammatory diseases of the connective tissue, gynecological diseases and migraine [10]. The biological activity of this plant is mainly due to sesquiterpene lactones, which are approximately 30 , phenolic compounds, such as flavonoids, hydroxycinnamic acids, coumarins, organic acids $[11,12,13,14]$.
The aim of the work was to analyze the degree of accumulation of macro- and microelements of the feverfew herb in 7 batches collected in 7 regions of Ukraine.

\section{Materials and methods}

The study object was batches of the feverfew herb collected in Kharkiv (Rs 868), Zhytomyr (Rs 864), Cherkasy (Rs 865), Sumy (Rs 866), Dnipropetrovsk (Rs 867), Poltava (Rs 869), and Kiev (Rs 870) regions. The batches of the medicinal plant raw material were registered in the State Enterprise "Ukrainian Scientific Pharmacopoeial Center for Quality of Medicines".

The qualitative composition and quantitative content of the elements were determined using the atomic emission spectroscopy method at the Laboratory of Analytical Chemistry of Functional Materials and Environmental Objects of the STC "Institute for Single Crystals", National Academy of Sciences of Ukraine (Kharkiv) using a CAS-120 device, manufacturing group "Electron" by atomization in air-acetylene flame. Analytical parameters were the following: pressure $-0.4 \mathrm{~kg} / \mathrm{cm}^{2}$, flame temperature $-2250^{\circ} \mathrm{C}$. The plant material samples were pretreated with diluted sulfuric acid with further carbonization in a muffle furnace under the temperature of $500{ }^{\circ} \mathrm{C}$ and evaporation from graphite electrode craters in $\mathrm{AC}$ arc discharge at $16 \mathrm{~A}$ current and $60 \mathrm{sec}$ exposure. Registration of the samples was carried out on a DFS-8 spectrograph, estimation of the line intensity in the spectra - by a MPh-1 microphotometer. The spectra were photographed in the wavelength range of $230-330 \mathrm{~nm}$. The calibration plots were built using the standard samples of solutions of metal salts (ICOMP-23-27) $[15,16]$. 
Table

The results of the study of the qualitative composition and quantitative content of macro- and microelements in the batches of the feverfew herb

\begin{tabular}{|l|c|c|c|c|c|c|c|}
\hline \multirow{2}{*}{ Element } & \multicolumn{6}{|c|}{ The content of elements in batches of the raw material, $\mu \mathrm{g} / 100 \mathrm{~g}$} \\
\cline { 2 - 8 } & Rs 864 Zh. & Rs 865 Ch. & Rs 866 S. & Rs 867 Dn. & Rs 868 Kh. & Rs 869 P. & Rs 870 K. \\
\hline Sodium (Na) & 96.0 & 63.0 & 68.0 & 135.0 & 84.0 & 50.0 & 65.0 \\
\hline Magnesium (Mg) & 340.0 & 240.0 & 136.0 & 270.0 & 480.0 & 295.0 & 200.0 \\
\hline Silicon (Si) & 360.0 & 315.0 & 68.0 & 335.0 & 480.0 & 150.0 & 120.0 \\
\hline Phosphorus (P) & 180.0 & 135.0 & 100.0 & 145.0 & 300.0 & 195.0 & 95.0 \\
\hline Potassium (K) & 3000.0 & 2765.0 & 2040.0 & 2145.0 & 3840.0 & 2940.0 & 2430.0 \\
\hline Calcium (Ca) & 840.0 & 790.0 & 545.0 & 670.0 & 1080.0 & 785.0 & 610.0 \\
\hline Aluminum (Al) & 60.0 & 23.7 & 8.1 & 32.1 & 72.0 & 24.5 & 14.6 \\
\hline Iron (Fe) & 48.0 & 9.5 & 5.4 & 23.4 & 42.0 & 14.7 & 5.3 \\
\hline Manganese (Mn) & 18.0 & 7.1 & 6.8 & 8.4 & 9.0 & 18.6 & 4.1 \\
\hline Nickel (Ni) & 0.12 & 0.08 & 0.05 & 0.06 & 0.06 & 0.05 & 0.04 \\
\hline Copper (Cu) & 1.25 & 3.16 & 0.68 & 0.6 & 1.2 & 1.1 & 1.0 \\
\hline Zink (Zn) & 12.0 & 5.5 & 3.4 & 3.3 & 14.4 & 14.7 & 2.4 \\
\hline Lead (Pb) & $<0.03$ & 0.06 & 0.07 & $<0.03$ & 0.05 & 0.08 & $<0.03$ \\
\hline Molybdenum (Mo) & 0.06 & 0.06 & 0.07 & 0.03 & 0.06 & 0.06 & 0.05 \\
\hline
\end{tabular}

Notes: $\mathrm{Co}<0.03 ; \mathrm{Cd}<0.01 ; \mathrm{As}<0.01 ; \mathrm{Hg}<0.01$; regions of collecting the raw material: Zh. - Zhytomyr, Ch. - Cherkasy, S. - Sumy, Dn. Dnipropetrovsk, Kh. - Kharkiv, P. - Poltava, K. - Kyiv.

\section{Results and discussion}

The results of studying the elemental composition in the batches of the feverfew herb are shown in Table.

As a result of the study conducted 18 elements were identified in all batches of the raw material, and their content was determined. Potassium, calcium, silicon and magnesium contained in the largest quantities there. The prevailing amount of potassium was determined in the samples from the Kharkiv, Zhytomyr and Poltava regions $(3840 \mu \mathrm{g} / 100 \mathrm{~g}, 3000 \mu \mathrm{g} / 100 \mathrm{~g}, 2940 \mu \mathrm{g} / 100 \mathrm{~g})$. Calcium predominated in the samples of the raw material from the Kharkiv, Zhytomyr and Cherkasy regions $(1080 \mu \mathrm{g} / 100 \mathrm{~g}$, $840 \mu \mathrm{g} / 100 \mathrm{~g}, 790 \mu \mathrm{g} / 100 \mathrm{~g})$. The highest content of silicon and magnesium was observed in the samples from the Kharkiv and Zhytomyr regions, slightly smaller amount in the samples from the Dnipropetrovsk and Poltava regions. A rather high content of copper was determined in the sample from the Cherkasy region $-3.16 \mu \mathrm{g} / 100 \mathrm{~g}$. After analyzing the degree of accumulation of elements in the batches of the raw material it was determined that the elements in the samples from the Zhytomyr, Cherkasy and Dnipropetrovsk regions accumulated in the following order: $\mathrm{K}>\mathrm{Ca}>\mathrm{Si}>\mathrm{Mg}>\mathrm{P}>\mathrm{Na}>\mathrm{Al}>\mathrm{Fe}>\mathrm{Mn}>\mathrm{Zn}>$ $\mathrm{Cu}>\mathrm{Ni}>\mathrm{Mo}>\mathrm{Pb}$. In the samples from the Sumy and Poltava regions the degree of accumulation of elements was the same and corresponded to the following order: $\mathrm{K}>\mathrm{Ca}>\mathrm{Mg}>\mathrm{P}>\mathrm{Si}>\mathrm{Na}>\mathrm{Al}>\mathrm{Mn}>\mathrm{Fe}>\mathrm{Zn}>\mathrm{Cu}$.

The content of potassium, calcium, sodium, aluminum, and copper was also observed at the same level in all batches of the raw material. Therefore, one can assume that their content in the raw material is quite stable regardless of the place of growth of the species. The content of the other elements varied slightly in different batches.

Nickel, molybdenum and lead were in the least quantity among the microelements in the feverfew herb. The content of nickel ranged from 0.04 to $0.12 \mu \mathrm{g} / 100 \mathrm{~g}$, the content of molybdenum - from 0.03 to $0.07 \mu \mathrm{g} / 100 \mathrm{~g}$. A relatively high content of lead was observed in the samples of the raw material from the Poltava, Sumy and Cherkasy regions (from 0.06 to $0.08 \mu \mathrm{g} / 100 \mathrm{~g}$ ) It may indicate that the area where the these samples were collected is quite polluted. The content of such heavy metals as cobalt, cadmium, arsenic and mercury was within the maximum permissible limits, meeting the requirements for the raw material and food products [17].

\section{CONCLUSIONS}

For the first time the study of the mineral composition of samples of the feverfew herb from different regions of Ukraine was carried out using the atomic emission spectroscopy. The studies conducted have shown that all samples are characterized by the prevalent accumulation of potassium, calcium, silicon, magnesium from macroelements, aluminum and iron from microelements. The highest content of all elements is observed in the samples of the raw material from the Kharkiv, Zhytomyr and Poltava regions compared to other batches.

Conflict of Interests: authors have no conflict of interests to declare. 


\section{REFERENCES}

1. Макро- та мікроелементи (обмін, патологія та методи визначення): монографія / М. В. Погорєлов, В. І. Бумейстер, Г. Ф. Ткач та ін. Суми: Вид-во СумДУ, 2010. - 147 с.

2. Soetan, K. O. The importance of mineral elements for humans, domestic animals and plants: A review / K. O. Soetan, C. O. Olaiya, O. E. Oyewole // African J. of Food Sci. - 2010. - Vol. 4 (5). - P. 200-222.

3. Ржевский, С. Г. Сравнительный анализ элементного состава Artemisia latifoliali deb. и Artemisia armeniaca Lam // Научные ведомости БелГУ. Серия : Естественные науки. - 2017. - № 18 (267). - С. 5-10.

4. Скальный, А. В. Биоэлементы в медицине / А. В. Скальный, И. А. Рудаков. - М. : ИД «Оникс 21 век»; Мир, $2004 .-272$ с.

5. Фоновий вміст мікроелементів у грунтах України / за ред. А. І. Фадеєва, Я. В. Пащенко. - Х. : Прапор, 2003. - 115 с.

6. The study of nitrates and inorganic elements compositions contents in types of genus Carduus L. herbs and extracts / T. I. Balanchuk, A. V. Mazulin, T. V. Oproshanska, A. O. Ostapenko // Укр. біофармац. журн. - 2016. - № 6. - C. 75-79. https://doi.org/10.24959/ ubphj.16.86

7. Bardarov, K. Study on the elemental composition of Clinopodium Vulgare L / Bardarov, Krum\&Mihaylova, Veronika\&Djingova, R. // Bulgarian J. of Agricultural Sci. - 2015. - № 21. - P. 151-158.

8. Mohsenzadeh, F. Chemical composition, antibacterial activity and cytotoxicity of essential oils of Tanacetum parthenium in different developmental stages. / F. Mohsenzadeh, A. Chehregani, H. Amiri // Pharmac. Biol. - 2011. - Vol. 49 (9). - P. 920-926. https://doi.org/10.3109/ 13880209.2011.556650

9. Farzadfar, S. Magnesium and manganese affect photosynthesis, essential oil composition and phenolic compounds of Tanacetum parthenium / S. Farzadfar, F. Zarinkamar, M. Hojati // Plant Physiol. and Biochem. - 2017. - Vol. 112. - P. 207-217. https://doi org/10.1016/j. plaphy.2017.01.002

10. Feverfew (Tanacetum parthenium L.) : A systematic review / A. Pareek, M. Suthar, G. S. Rathore, V. Bansal // Pharmacognosy Rev. 2011. - № 5 (9). - P. 103-110. https://doi.org/10.4103/0973-7847.79105

11. Коновалова, Д. С. Сесквитерпеновые лактоны пиретрума девичьего как биологически активные вещества / Д. С. Коновалова, Д. А. Коновалов // Экол. человека. - 2008. - № 3. - С. 3-7.

12. A combination of coenzyme Q10, feverfew and magnesium for migraine prophylaxis: a prospective observational study / A. Guilbot, M. Bangratz, S. AitAbdellah, C. Lucas // BMC Complementary and Alternative Med. - 2017. - № 17. - P. 433-439. https:// doi org/10.1186/s12906-017-1933-7

13. Parthenolide : from plant shoots to cancer roots / A. Ghantous, A. Sinjab, Z. Herceg, N. Darwiche // Drug Discov. Today. - 2013. P. 894-905. https://doi.org/10.1016/j.drudis.2013.05.005

14. Maizels, M. A combination of riboflavin, magnesium, and feverfew for migraine prophylaxis: a randomized trial / M. Maizels, A. Blumenfeld, R. A. Burchette // Headache. - 2004. - № 44. - P. 885-890. https://doi.org/10.1111/j.1526-4610.2004.04170.x

15. Гонтова, Т. М. Вивчення вітамінного та елементного складу трави та бульб жоржини німфейної сорту Кеп'sflame / Т. М. Гонтова, Я. С. Кічимасова, Н. І. Ільїнська // Зб. наук. праць співробітників НМАПО імені П. Л. Шупика. - 2014. - Вип. 23 (4). С. 245-249.

16. Золотайкина, М. Ю. Накопление элементов в сырье пижмы обыкновенной в зависимости от места / М. Ю. Золотайкина, Т. Н. Гонтовая // Рецепт. - 2016. - Т. 19, № 1. - С. 26-30.

17. Медико-биологические требования и санитарные нормы качества продовольственного сырья и пищевых продуктов. - М., 1990. $155 \mathrm{c}$.

\section{REFERENCES}

1. Pohorielov, M. V., Bumeister, V. I., Tkach, H. F., Bonchev, S. D., Sikora, V. Z., Sukhodub, L. F.,Danylchenko, S. M. (2010). Makro- ta mikroelementy (obmin, patolohiia ta metody vyznachennia): monohrafiia. Sumy: Vyd-voSumDU, 147.

2. Soetan, K. O., Olaiya, C. O., Oyewole, O. E. (2010). The importance of mineral elements for humans, domestic animals and plants: A review. African Journal of Food Science, 4 (5), 200-222.

3. Rzhevskii, S. G. (2017). Nauchnye vedomosti BelGU. Seriia: Estestvennye nauki, 18 (267), 5-10.

4. Skalnyi, A. V., Rudakov, I. A. (2004). Bioelementyi v meditsine, Moscow: Izd. dom «Oniks 21 vek»: Mir, 272.

5. Fadeieva, A. I., Pashchenko, Ya. V. (Eds.). (2003).Fonoviy vmist mikroelementiv u gruntah Ukrayini, Kharkiv: "Prapor”, 115.

6. Balanchuk, T. I., Mazulin, A. V., Oproshanska, T. V., Ostapenko, A. O. (2016). The study of nitrates and inorganic elements compositions contents in types of genus Carduus L. herbs and extracts. Ukraïns'kij biofarmacevtičnij žurnal, 6, 75-79. https://doi.org/10.24959/ ubphj.16.86

7. Bardarov, Krum\&Mihaylova, Veronika\&Djingova, R. (2015). Study on the elemental composition of Clinopodium Vulgare L. Journal of Agricultural Science, 21, 151-158.

8. Mohsenzadeh, F., Chehregani, A., \& Amiri, H. (2011). Chemical composition, antibacterial activity and cytotoxicity of essential oils of Tanacetum parthenium in different developmental stages. Pharmaceutical Biology, 49 (9), 920-926. https://doi.org/10.3109/13880209.2011.556650

9. Farzadfar, S., Zarinkamar, F., \&Hojati, M. (2017). Magnesium and manganese affect photosynthesis, essential oil composition and phenolic compounds of Tanacetum parthenium. Plant Physiology and Biochemistry, 112, 207-217. https://doi.org/10.1016/j.plaphy.2017.01.002

10. Pareek, A., Suthar, M., Rathore, G., \&Bansal, V. (2011). Feverfew (Tanacetum parthenium L.): A systematic review. Pharmacognosy Reviews, 5(9), 103. https://doi.org/10.4103/0973-7847.79105

11. Konovalova, D. S., Konovalov, D. A. (2008). Ekologiya cheloveka, 3, $3-7$.

12. Guilbot, A., Bangratz, M., AitAbdellah, S., \& Lucas, C. (2017). A combination of coenzyme Q10, feverfew and magnesium for migraine prophylaxis: a prospective observational study. BMC Complementary and Alternative Medicine, 17(1). https://doi.org/10.1186/s12906017-1933-7 
13. Ghantous, A., Sinjab, A., Herceg, Z., \&Darwiche, N. (2013). Parthenolide: from plant shoots to cancer roots. Drug Discovery Today, 18(17-18), 894-905. https://doi.org/10.1016/j.drudis.2013.05.005

14. Maizels, M., Blumenfeld, A., \&Burchette, R. (2004). A Combination of Riboflavin, Magnesium, and Feverfew for Migraine Prophylaxis: A Randomized Trial. Headache: The Journal of Head and Face Pain, 44(9), 885-890. https://doi.org/10.1111/j.1526-4610.2004.04170.x

15. Gontova, T. M., Kichimasova, Ya. S., Ilinskaya, N. I. (2014).Zbirnik naukovih prats spivrobitnikiv NMAPO im. P. L. Shupika (Ukraine), 23 (4), 245-249.

16. Zolotaykina, M. Yu., Gontova, T. M. (2016). Retsept 19, (1), 26-30.

17. Mediko-biologicheskie trebovaniia i sanitarnye normy kachestva prodovolstvennogo syria i pishchevykh produktov. (1990). Moscow, 155.

\section{Information about authors:}

Hordiei K. R., postgraduate student of the Botany Department, National University of Pharmacy. E-mail: 95karisha95@gmail.com.

ORCID: https://orcid.org/0000-0001-8954-9435

Gontova T. M., Doctor of Pharmacy (Dr. habil), professor, head of the Botany Department, National University of Pharmacy. E-mail: tetianaviola@ukr.net.

ORCID: https://orcid.org/0000-0003-3941-9127

Zolotaikina M. Yu., external PhD student of the Botany Department, National University of Pharmacy. E-mail: pizma89@ukr.net

Відомості про авторів:

Гордєй К. Р., аспірант кафедри ботаніки, Національний фармацевтичний університет. E-mail: 95karisha95@gmail.com.

ORCID: https://orcid.org/0000-0001-8954-9435

Гонтова Т. М., д-р фарм. наук, професор, завідувач кафедри ботаніки, Національний фармацевтичний університет. E-mail: tetianaviola@ukr.net.

ORCID: https://orcid.org/0000-0003-3941-9127

Золотайкіна М. Ю., здобувач кафедри ботаніки, Національний фармацевтичний університет. E-mail: pizma89@ukr.net

Информация об авторах:

Гордей К. Р., аспирант кафедры ботаники, Национальный фармацевтический университет. E-mail: 95karisha95@gmail.com.

ORCID: https://orcid.org/0000-0001-8954-9435

Гонтовая Т. Н., д-р фарм. наук, профессор, заведующая кафедрой ботаники, Национальный фармацевтический университет. Е-таil: tetianaviola@ukr.net.

ORCID: https://orcid.org/0000-0003-3941-9127

Золотайкина М. Ю., соискатель кафедры ботаники, Национальный фармацевтический университет. E-mail: pizma89@ukr.net 